\title{
Pannexin channel and connexin hemichannel expression in vascular function and inflammation
}

\author{
Daniela Begandt ${ }^{1 \dagger}$, Miranda E Good ${ }^{1 \dagger}$, Alex S. Keller ${ }^{1}$, Leon J. DeLalio ${ }^{1}$, Carol Rowley ${ }^{1}$, Brant E. Isakson ${ }^{1,2}$ \\ and Xavier F. Figueroa ${ }^{3^{*}}$
}

From International Gap Junction Conference 2015

Valparaiso, Chile. 28 March - 2 April 2015

\begin{abstract}
Control of blood flow distribution and tissue homeostasis depend on the tight regulation of and coordination between the microvascular network and circulating blood cells. Channels formed by connexins or pannexins that connect the intra- and extracellular compartments allow the release of paracrine signals, such as ATP and prostaglandins, and thus play a central role in achieving fine regulation and coordination of vascular function. This review focuses on vascular connexin hemichannels and pannexin channels. We review their expression pattern within the arterial and venous system with a special emphasis on how post-translational modifications by phosphorylation and S-nitrosylation of these channels modulate their function and contribute to vascular homeostasis. Furthermore, we highlight the contribution of these channels in smooth muscle cells and endothelial cells in the regulation of vasomotor tone as well as how these channels in endothelial cells regulate inflammatory responses such as during ischemic and hypoxic conditions. In addition, this review will touch on recent evidence implicating a role for these proteins in regulating red blood cell and platelet function.
\end{abstract}

Keywords: Connexins, Pannexins, Vasculature, Inflammation, Endothelium, Smooth muscle

\section{Background}

The vascular system is a complex network that, according to the structure and function of the vessels, can be divided into two compartments: the arterial and venous circulations, which are connected through the capillaries. Both compartments can be subdivided into different vascular segments. In the arterial circulation, conduit arteries, resistance arteries and arterioles can be recognized, and in the venous circulation, post-capillary venules, venules and veins can be distinguished [1-3]. All these vascular segments are designed to perform different, but

\footnotetext{
* Correspondence: xfigueroa@bio.puc.cl

${ }^{\dagger}$ Equal contributors

${ }^{3}$ Departamento de Fisiología, Facultad de Ciencias Biológicas, Pontificia

Universidad Católica de Chile, Santiago, Chile

Full list of author information is available at the end of the article
}

complementary functions in order to provide oxygen and nutrients to all individual cells of the organism and dispose of metabolic wastes, which can only be achieved by fine regulation and coordination of vascular function along the different segments. As blood vessels are complex structures formed by several cell types, control of vascular function depends on timely and precise communication between the different cellular components of the vessel wall, mainly smooth muscle cells (SMCs) and endothelial cells (ECs) [4-6]. Nevertheless, blood vessels must also work in coordination with cells that are part of the blood, such as red blood cells (RBCs) and platelets [7, 8]. Thus, the control of vascular function depends on the fine communication between diverse cell types that are not always in direct contact each other. 
One important mechanism of cell-to-cell communication is mediated by the release of autocrine/paracrine signals. Nitric oxide (NO), prostaglandins and ATP are widely recognized autocrine/paracrine signals that play diverse roles in the control of vascular function, such as regulation of vasomotor tone, smooth muscle proliferation, platelet aggregation, vascular permeability and leucocyte transmigration [9-12]. In addition, a signaling mechanism known as endothelium-derived hyperpolarization (EDH) has also been found to play an important role in the control of vasomotor tone [4, 9-14]. Although the biochemical identity of this signal is still controversial, it has been consistently found that the initiation of EDH signaling depends on the hyperpolarization of ECs by the activation of $\mathrm{Ca}^{2+}$-activated $\mathrm{K}^{+}$channels of small $\left(\mathrm{SK}_{\mathrm{Ca}}\right)$ and intermediate $\left(\mathrm{IK}_{\mathrm{Ca}}\right)$ conductance, which, in the vascular wall, are only expressed in the endothelium [4, 9-13]. Additionally to autocrine/paracrine signaling, the direct cell-to-cell communication via connexin-formed gap junction channels make an important contribution to the coordination of function between the different cell types of the vessel wall and among distinct segments of the vascular network in the microcirculation [15-17]. It is interesting to note that ECs and SMCs are functionally connected by gap junctions, which led to hypothesize that the EDH signaling corresponds to direct transmission of the hyperpolarizing current generated in ECs to SMCs through a gap junction-mediated pathway $[4,13]$.

Remarkably, connexin $(\mathrm{Cx})$ proteins do not form only gap junction channels, but also may form functional hemichannels (i.e. half of a gap junction channel) that connect the cytoplasm with the extracellular milieu. Communication of the intracellular compartment with the extracellular space through low resistance membrane channels formed by connexins (i.e. gap junctions) or the structurally related proteins termed pannexins (Panxs) has emerged as key pathways to command and regulate several paracrine signaling mechanisms involved in the control of vascular function [4, 18-21]. In this review, we discuss the structure, regulation and function of gap junctions, connexin hemichannels and pannexin channels in the vasculature and briefly in the circulating anuclear cells that regulate vascular function, red blood cells (RBCs) and platelets.

\section{Structure of Connexin and Pannexin Proteins}

Connexin and pannexin proteins are thought to belong to the same superfamily as they share some physic-chemical properties, such as the charged nature of the extracellular loop and the polar residue distribution in the transmembrane helices [22]. However, it remains to be determined if they evolved from a common ancestor or if they evolved convergently. All connexins and pannexins possess a similar structure with 4 transmembrane domains, two extracellular loops, an intracellular loop, and both the amino and carboxyl termini located intracellularly [23]. Generally, either six connexins or six pannexins come together and form a channel, except for Panx2 that seems to form heptamers or octamers [24]. A connexin-based hexamer is referred to as a connexin hemichannel [25]. Two connexin hemichannels from adjacent cells are able to dock and form a gap junction channel. Pannexin oligomers form pannexin channels in the membrane, similar to connexin hemichannels; however, there is limited evidence in vertebrates for pannexin channels to dock with channels of neighboring cells to form functional pannexin-formed gap junction channels [26].

In the human genome, there are 21 known isoforms of connexins that were originally grouped into three subfamilies, $\alpha, \beta$, and $\gamma$; however, recent analyses of the evolution of connexins have regrouped them into five subfamilies, adding $\delta$ and $\zeta[22]$. Cx32, Cx37, Cx40, $\mathrm{Cx} 43, \mathrm{Cx} 45$ and $\mathrm{Cx} 47$ are expressed in the vascular system, where $\mathrm{Cx} 37, \mathrm{Cx} 40$ and $\mathrm{Cx} 43$ are alpha connexins, $\mathrm{Cx} 45$ and $\mathrm{Cx} 47$ are gamma connexins, and $\mathrm{Cx} 32$ is a beta connexin [22]. All connexin isoforms have conserved regions of the second transmembrane domain, within the amino termini, and conserved cysteine residues in the extracellular loops [22]. The cytoplasmic loop and carboxyl terminus are the least conserved regions between connexins allowing for differential regulation of each connexin isoform and thus participation in unique signaling cascades, especially when multiple isoforms are expressed within the same cell [22]. Unlike connexins, there are only three mammalian pannexin isoforms, Panx1, Panx2 and Panx3, which share conserved regions in their extracellular loops, intracellular loop, and amino and carboxyl termini $[20,22,26]$. Panx1 and Panx2 each have two splice variants while the connexins are suggested to have splicing variants of their 5'-untranslated region, which can impact the translation and function of the proteins $[26,27]$.

\section{Connexin and pannexin expression in the vascular wall}

Connexins and pannexins are expressed throughout the cardiovascular system. The expression levels within the vascular tree are dependent upon vessel type, localization within the vessel, and the species being examined. The expression differences between macrovessels vs. microvessels and arteries vs. veins are continuing to be examined; however, the specificity of antibodies and detection of low expression levels remain limiting steps to overcome. The majority of the data of pannexin and connexin isoforms and their unique localizations along the vascular tree comes from studies using rodent models or human primary cells. Thus, species-dependent differences also add another level of complexity to our understanding of the localization and function of these isoforms within the vascular wall. Below is a 
brief description of the current knowledge regarding the expression of connexins and pannexins within the vascular wall (Table 1 ).

\section{Connexin expression in the vascular wall}

Cx43 is, by far, the most studied connexin. It has been well characterized and found to be expressed in the vascular SMCs of large conduit vessels, such as the aorta, in numerous species [28, 29]. The SMCs from mouse and human resistance arteries and veins can also express Cx43 [30-33]. Isolated primary human SMCs and ECs from arteries and veins express Cx43 [33-35]. In vivo, Cx43 is expressed in arterial ECs of larger arteries only in areas of non-laminar flow, such as branching points, as well as in arterioles and capillaries, such as in the brain $[29-31,36,37]$. In the murine vasculature, $C x 43$ is expressed by ECs of non-valved veins, such as the inferior vena cava, but in valved veins, such as the saphenous vein, is expressed solely in the ECs composing valves $[36,38,39]$. Together the literature indicates that Cx43 is expressed in both SMCs and ECs of both arterial and venous vessels; however, localization and expression levels are species- and vessel-specific. Cx43 is regularly shown to be expressed in cell lines; however, this expression may be increased or induced after the cells have been cultured because they are no longer under normal flow conditions or polarized with the physiologically appropriate neighboring cells.

Cx37 and Cx40 are also found broadly across the vascular network. Cx40 is predominantly expressed in ECs; however, a weak expression of $\mathrm{Cx} 40$ may also be observed in SMCs such as rat brain vessels [32]. Cx40 is

Table 1 Expression pattern of connexin and pannexin isoforms in vivo along the vascular tree. EC: endothelial cells; SMC: smooth muscle cells. 'no' indicates that a protein has yet to be identified in those size vessels, not that the protein is necessarily absent. Expression pattern varies between vascular beds

\begin{tabular}{|c|c|c|c|c|c|c|}
\hline Protein & Large Arteries & $\begin{array}{l}\text { Resistance Arteries } \\
\text { and Arterioles }\end{array}$ & Capillaries & $\begin{array}{l}\text { Post-Capillary Venules } \\
\text { and Venules }\end{array}$ & Veins & References \\
\hline \multicolumn{7}{|c|}{ Endothelial Cell Expression } \\
\hline $\mathrm{C} \times 32$ & $\begin{array}{l}\text { only in isolated } \\
\text { primary cell line }\end{array}$ & $\begin{array}{l}\text { only in isolated } \\
\text { primary cell line }\end{array}$ & no & $\begin{array}{l}\text { no (low levels in primary } \\
\text { human cell lines) }\end{array}$ & yes & {$[43]$} \\
\hline Cx37 & yes & yes & yes & $\begin{array}{l}\text { downstream side of } \\
\text { valved-veins and in } \\
\text { some ECs of the wall } \\
\text { of non-valved veins }\end{array}$ & $\begin{array}{l}\text { downstream side of } \\
\text { valved-veins and in } \\
\text { some ECs of the wall } \\
\text { of non-valved veins }\end{array}$ & {$[28-30,33,36-39]$} \\
\hline Cx40 & yes & yes & no & no & generally no & {$[28,29,32,33,36,37,39]$} \\
\hline Cx43 & $\begin{array}{l}\text { predominately areas } \\
\text { of non-laminar flow }\end{array}$ & yes & yes & $\begin{array}{l}\text { upstream side of } \\
\text { valved-veins and in } \\
\text { some ECs of the wall } \\
\text { of non-valved veins }\end{array}$ & $\begin{array}{l}\text { upstream side of } \\
\text { valved-veins and in } \\
\text { some ECs of the wall } \\
\text { of non-valved veins }\end{array}$ & {$[28-30,32,33,35-39]$} \\
\hline Cx45 & yes & no & no & no & no & {$[41,42]$} \\
\hline Cx47 & no & no & no & $\begin{array}{l}\text { only subset of ECs that } \\
\text { compose the valves }\end{array}$ & $\begin{array}{l}\text { only subset of ECs } \\
\text { that compose the } \\
\text { valves }\end{array}$ & {$[38]$} \\
\hline Panx1 & yes & yes & yes & yes & no & {$[35,44-46]$} \\
\hline $\operatorname{Pan} \times 2$ & yes & yes & no & no & no & {$[44,46]$} \\
\hline Panx3 & no & $<100 \mu m$ diameter & no & no & no & {$[44,45]$} \\
\hline \multicolumn{7}{|c|}{ Smooth Muscle Cell Expression } \\
\hline $\mathrm{C} \times 32$ & no & no & & no & no & {$[43]$} \\
\hline $\mathrm{C} \times 37$ & yes & yes & & no & yes & {$[30,33,36,37]$} \\
\hline Cx40 & no & generally no & & no & no & {$[32]$} \\
\hline Cx43 & yes & yes & & no & yes & {$[28,30,32,33,35-37]$} \\
\hline Cx45 & yes & yes & & yes & no & {$[28,33,37,42]$} \\
\hline Cx47 & no & no & & no & no & {$[38]$} \\
\hline Panx1 & no & yes & & yes & no & [44-46] \\
\hline $\operatorname{Pan} \times 2$ & yes & yes & & no & no & {$[44,46]$} \\
\hline Panx3 & no & $<100 \mu \mathrm{m}$ diameter & & no & no & {$[44,45]$} \\
\hline
\end{tabular}


rarely observed in the venous vasculature, although a few studies have found expression in murine umbilical cord vein, portal vein, and in human umbilical vein ECs (HUVECs) [33, 36, 39, 40]. Cx37 expression in SMCs has been demonstrated in arteries of various diameters from various organs as well as in isolated primary human SMCs [30, 31, 33, 36, 37]. It was specifically noted that $\mathrm{Cx} 37$ is not found in veins from the coronary or splenic circulations, although weak expression was found in veins from other sections of the vascular tree $[36,38,39]$. However, Cx37 is strongly expressed in ECs that compose the valves in valved veins such as the saphenous vein, but similar to $\mathrm{Cx} 43$, it is not expressed in the surrounding non-valvular ECs of valved veins [38]. Cx40 and Cx37 are both expressed in ECs of mice and rats throughout the arterial tree as well as in isolated human ECs [28, 30-34, 36, 37, 40].

Less information is available about the roles and localization of Cx32, Cx45 and Cx47. A weak signal for Cx45 has been observed in ECs from the bovine aorta [41], but Cx45 expression is predominantly in SMCs as well as in cultured HUVSMCs [28, 33, 37, 42]. Although expression of $\mathrm{Cx} 32$ in vivo has only been reported in ECs of large murine veins, the analysis of primary cultures of human ECs suggest that Cx32 has significantly higher expression in ECs from larger vessels, such as HUVECs and HAECs, as compared to ECs from microvessels, such as cultured human microvascular ECs (HMVECs) [43]. Cx47 has recently been found within a small subset of ECs that compose the valves in veins [38]. As the information about these connexins (Cx32, Cx45 and $\mathrm{Cx} 47)$ is just emerging, further studies are necessary to determine their expression and functional roles within the vasculature.

\section{Pannexin expression in the vascular wall}

Pannexin channels are expressed throughout the body. The expression of these channels continues to be explored, but recent data indicate that Panx1 is almost ubiquitously expressed in murine ECs within arteries, arterioles, and venules, as well as in isolated human cells including an immortalized brain EC line, human saphenous vein ECs (HSaVECs), and HUVECs [35, 44, 45]. Panx1 expression in murine SMCs occurs only in arterioles and venules, while Panx3 is only found in arterioles $<100 \mu \mathrm{m}$ in diameter $[44,45]$. Panx 2 has been observed in SMCs of the pulmonary artery of mice and in the SMCs of the rat middle cerebral artery (MCA) [44, 46]. Although mRNA of all three pannexin isoforms were found in the rat MCA, only Panx1 and Panx2 proteins were found in ECs of these vessels [46]. Lastly, as with any membrane bound protein that is expressed endogenously in low levels, it is rather difficult to detect Pannexin mRNA from small vessels. False-negative detection is a rather common occurrence and thus can not be taken to mean a lack of expression. For this reason, protein detection in small vessels in particular, is the most definitive way to detect Pannexin 1; this in conjunction with a knockout animal to validate expression. Overall, mouse and human expression appear to be the most consistent and reliable expression patterns, and thus physiologically relevant set of models, whereas the rat appears to be more random in expression.

\section{Regulation of connexin and pannexin function in the vascular wall}

Regulation of connexin hemichannels and pannexin channels can occur via changes in extracellular and intracellular $\mathrm{Ca}^{2+}, \mathrm{pH}$ or cell membrane voltage or via post-translational modifications (PTMs). PTMs are covalent protein modifications that alter protein function via the addition or removal of chemical functional groups to amino acid residues on the protein. A diverse array of PTMs exists, including phosphorylation, S-nitrosylation, glycosylation and ubiquitination, among others. These PTMs have individual effects on protein function but can also act in concert with other PTMs to regulate complex physiological responses [35]. Protein modifications by phosphorylation and S-nitrosylation are central regulators of vascular function due to the large influence of nitric oxide synthase and kinase-mediated signaling pathways during vasomotor responses in both arteries and veins [47, 48]. Research on connexin hemichannels and pannexin channels reveals evidence that the activity of these channels can be regulated by phosphorylation. Understanding how phosphorylation and S-nitrosylation modulates channel function is critical for understanding how connexin hemichannels and pannexin channels contribute to vascular homeostasis $[49,50]$.

\section{Phosphorylation of connexin hemichannels}

In the blood vessel wall, connexin hemichannels and gap junction channels assist in coordinating vasoconstrictor and vasodilator signaling between smooth muscle and endothelial cells [51]. Overall, a large body of research has been focused on the regulation of connexin gap junctions by phosphorylation, but far less information is available on the expression and functional control of connexin hemichannels in the vasculature [52]. Recently, a number of reports have observed that phosphorylation events on connexin hemichannels can alter channel permeability in cell culture [53]. However, there is limited information about the functional regulation of connexin hemichannels in vascular cells. Connexin hemichannels have been identified on ECs and SMCs [54-56]. In these cell types, connexin hemichannel activation is linked to the release of ATP, a key signaling molecule in the blood vessel wall [9]. Although the mechanistic gating of connexin hemichannels by 
phosphorylation is unclear in the vasculature, studies in other cell types has suggested that hemichannels can be directly regulated by kinases. Cx43 is a well-established phospho-substrate for mitogen-activated protein (MAP) kinases, as well as protein kinase $\mathrm{C}$ (PKC), which have been extensively reviewed elsewhere [52, 57-59]. Additionally, phosphorylation of $\mathrm{Cx} 43$ at amino acid serine residue S368 has been shown to reduce hemichannel opening, decrease permeability, and change ion selectivity $[60,61]$. This inhibitory effect was in part confirmed in the vascular endothelium, whereby hypoxia caused a reduction in ATP release, depletion of surface Cx43, and increased phosphorylation of Cx43 S368 [54]. It is interesting to note that the inhibitory effects of hypoxia on $\mathrm{Cx} 43$ hemichannels from cultured astrocytes have been linked to the dephosphorylation of $\mathrm{Cx} 43$ hemichannels by protein phosphatases, which suggests the existence of a complex PTM network in the regulation of $\mathrm{Cx} 43$ hemichannels by phosphorylation [52]. Nevertheless, future studies are needed to better understand how phosphorylation of connexin hemichannels modulates vascular function, especially in vivo.

\section{Phosphorylation of pannexin channels}

In addition to the presence of connexins in the vascular wall, pannexin channels have emerged as the most dominant regulator of extracellular purinergic signaling in vascular function [62-64]. A number of serine, threonine $(\mathrm{T})$ and tyrosine $(\mathrm{Y})$ phosphorylation sites have been predicted for pannexins based on their amino acid sequences, as well as putative recognition sites for protein kinase C (PKC), protein kinase A (PKA), and $\mathrm{Ca}^{2+} /$ calmodulin-dependent protein kinase (CamKII) (Fig. 1) [65-67]. However, there is still a lack of direct biochemical evidence to link specific amino acid/kinase pairs with channel function. The current landscape of Panx1 PTM by phosphorylation is dominated by the regulatory role of tyrosine phosphorylation, which plays a unique and crucial role in regulating vascular function [68-70].

Mechanistically, a link between pannexin channel gating and tyrosine kinase phosphorylation was established using Panx1-expressing 7778 macrophages and targeting the C-terminal Y308 amino acid of Panx1 in rodent hippocampal brain slices [71, 72]. In the vasculature, Lohman et al. recently confirmed the role for Src family kinase (SFK)-dependent tyrosine phosphorylation at residue Y198 of Panx1 in response to TNF $\alpha$-receptor stimulation in the venous endothelium [45]. In this study, stimulation of ECs with TNF $\alpha$ resulted in an SFK-dependent increase in phosphorylation of Panx1 at Y198, which was paralleled by an increase in SFK activity [45].

Moreover, the Panx1 Y198 site was suggested to regulate SMC contraction and vascular tone in resistance arteries [62]. Based on earlier work that characterized a novel interaction between the $\alpha 1$-adrenergic receptor and Panx1mediated ATP release, Billaud et al. demonstrated that pharmacological and genetic inhibition of the Panx1 intracellular loop motif containing Y198 prevents the Panx1 channel activation, ATP release, and vasoconstriction initiated by $\alpha 1$-adrenoceptor stimulation $[62,63]$. In addition, this study showed that SMC-specific Panx1 deletion in mice, which exhibit blunted phenylephrine (PE)-stimulated vasoconstrictor responses, could be rescued by transfecting wild type Panx1 plasmids directly into arterial SMCs, but not by plasmids containing a mutated Y198 motif. These investigations suggest that Panx1 tyrosine phosphorylation within both ECs and SMCs could play a role in the regulation of vascular function [45, 62]. However, this has yet to be proven definitely and likely is a part of a much larger PTM set of events that have yet to be uncovered.

Outside of tyrosine phosphorylation, little is known about regulation of pannexin by serine/threonine PTM. In one study using pan-phosphoserine/threonine antibodies, the electrical stimulation of skeletal muscle was shown to enhance serine/threonine phosphorylation of Panx1 [73]. The increase in phosphorylation was associated with ATP release and dye uptake, which was sensitive to channel blocking agents. In a second study, the Panx1 residue S206 has been put forth as a putative serine phosphorylation site by protein kinase G (PKG) [74]. The inhibitory effect of the nitric oxide donor sodium nitroprusside (SNP) on Panx1 channel currents was shown to act through a cGMP-PKG dependent mechanism, and mutation of the serine at residue 206 to alanine blunted the SNP-dependent inhibition of Panx1 channel currents [74]. However, this investigation did not directly demonstrate substrate specificity of PKG for S206. In the future, it will be important to determine if S206 phosphorylation by PKG negatively affects Panx1 channel activity as Panx1-mediated ATP release has been shown to control $\alpha 1$-adrenoceptor-induced vasoconstriction and PKG signaling pathways are known to cause cessation of vascular SMC contraction [62, 75].

\section{S-Nitrosylation of connexin hemichannels}

The addition of nitrosyl groups to cysteine $(C)$ residues (S-nitrosylation) is another important PTM in both physiological conditions and disease [76, 77]. For connexins, there is clear evidence that $\mathrm{NO}$ can influence gap junction function in the vasculature, in both ECs and SMCs [78-81]. However, limited evidence exists for the regulated gating of connexin hemichannels by S-nitrosylation in the blood vessel wall. The mechanisms by which NO regulates connexin hemichannel activity have primarily been investigated in the central nervous system, mainly in astrocytes $[53,82]$. However, it is important to note that both astrocytes and endothelial cells express the enzyme NO 


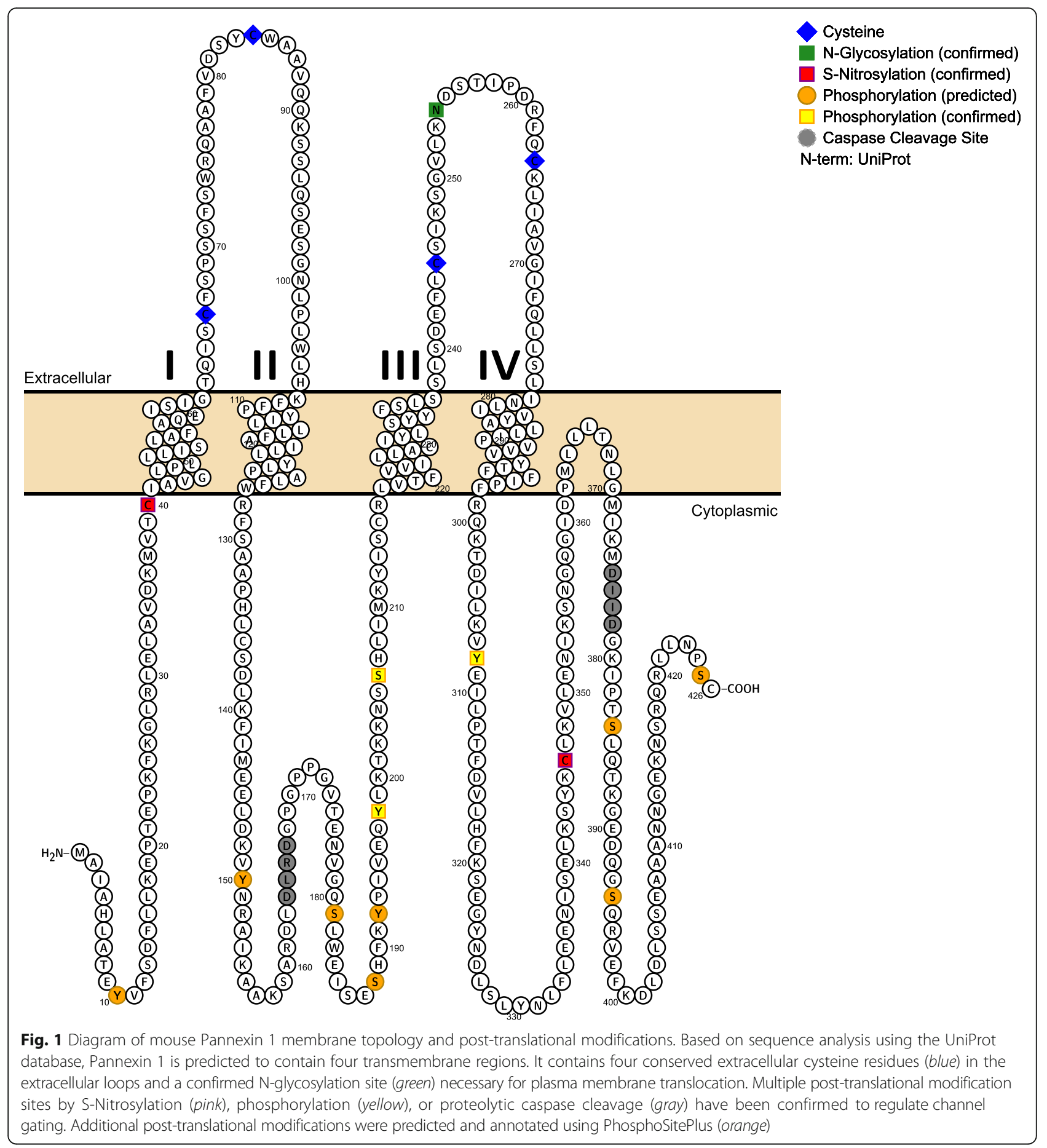

synthase (NOS), and thus, similarities may exist in the PTM mechanisms that regulate connexin hemichannel activity in these two cell types.

A number of studies have linked the regulation of connexin hemichannels with the production of NO. S-Nitrosylation has been proposed to regulate $\mathrm{Cx} 43$ hemichannels in astrocytes and cardiomyocytes, whereby conditions of oxygen deprivation and metabolic inhibition can enhance hemichannel activity as determined by pharmacology and in vitro $[83,84]$. The potential modulation of connexin hemichannels by NO-mediated events has been linked to the functional regulation of vasodilator responses. Using connexin-deficient HeLa cells, Figueroa et al. demonstrated that $\mathrm{Cx} 43, \mathrm{Cx} 40$, and $\mathrm{Cx} 37$ could be stimulated to open when treated with $\mathrm{NO}$ donors and additionally could act as a conduit for $\mathrm{NO}$ transmission 
[78]. The study further demonstrated that acetylcholine (ACh)-induced vasodilation and the diffusion of $\mathrm{NO}$ from ECs to SMCs could be blocked in mesenteric arteries by inhibiting connexin-based channels. However, future studies are needed to determine the extent to which NO-activated connexin hemichannels contribute to the regulation of vascular function.

\section{S-Nitrosylation of pannexin channels}

In addition to connexin hemichannels, evidence indicates that Panx1 channels can be regulated by S-nitrosylation. It was previously demonstrated that Panx1 channels can be activated by ischemic conditions in neurons, and that inhibition of the neuronal isoform of NOS (nNOS) during oxygen/glucose deprivation (OGD) blocks Panx1 channel activity in a NO-dependent and redox-sensitive manner $[85,86]$. Direct evidence for a potential PTM site at Panx1 residue $\mathrm{C} 28$ was later identified in zebrafish using targeted mutagenesis experiments on cysteine residues in the intracellular and transmembrane domains of Panx1 [87]. Two later studies revealed additional residues (C40 and C346) as potential PTM sites of Panx1 [88]. Mutations of these two individual residues to serines resulted in a constitutively active channel [88]. Moreover, substitution of any of the four extracellular cysteine residues in Panx1 (C66, C84, C245, and C264) resulted in complete loss of channel function [89].

Although the previous studies did not identify Panx1 PTM by S-nitrosylation in a physiological context, they did set the stage for an investigation by Lohman et al, which demonstrated that multisite S-nitrosylation may be important for Panx1 channel gating in the vasculature [90]. The treatment of HEK and HAECs with the NO donor S-nitrosoglutathione (GSNO) induced Panx1 S-nitrosylation; however, instead of activating Panx1 as observed in neurons, NO had an inhibitory effect on channel currents and ATP release. This inhibition could be reversed by the reducing agent DTT. Furthermore, dual mutation of both $\mathrm{C} 40$ and $\mathrm{C} 346$ residues to alanine, but not either point mutation alone, was necessary to prevent GSNO-stimulated inhibition of Panx1 channel currents and ATP release. The results of this study highlight a potential negative regulatory mechanism of Panx1 channel gating by S-nitrosylation, which may balance vasoconstrictor responses produced by Panx1-mediated ATP release in SMCs of resistance arteries [62]. More recently, a similar investigation looking at the effects of NO donors on Panx1 activity in human embryonic kidney 293 (HEK) cells confirmed the observation of Lohman et al that NO donors closed Panx1 channels [74]. However, in this investigation, a PKGdependent phosphorylation mechanism was suggested to participate in the control of channel activity, particularly by the stimulation of soluble guanylyl cyclase via NO. The mechanistic discrepancy between the two studies may be due to complex PTM regulatory signals, where multiple signaling cascades are involved in regulating pannexin channel gating as it relates to vascular function.

\section{Connexin hemichannels and pannexin channels in the control of vasomotor tone}

The regulation of blood flow distribution in the tissues relies on the well-integrated control of the microvascular resistance to blood flow by the adjustment of the diameter of resistance vessels, which depends on the level of constriction of SMCs (i.e. vasomotor tone). The contractile state of SMCs depends on the cytoplasmic $\mathrm{Ca}^{2+}$ concentration and $\mathrm{Ca}^{2+}$ sensitivity of the contractile machinery. Thereby, smooth muscle membrane potential plays a pivotal role in the regulation of vasomotor tone by temporally controlling the open probability of L-type, voltage-dependent $\mathrm{Ca}^{2+}$ channels $[91,92]$. However, it is important to note that vasomotor tone is finally determined by the balance between a smooth muscledependent constrictor tone and an endothelium-dependent vasodilator tone $[93,94]$.

\section{Connexins and pannexins in smooth muscle cell function}

The SMC-constrictor tone is mainly determined by the development of myogenic tone and the activity of the sympathetic system (i.e. sympathetic tone) $[95,96]$. Myogenic tone is an intrinsic property of vascular smooth muscle and corresponds to the ability of vessels to develop a basal tone in response to the intravascular blood pressure [96, 97]. Interestingly, development of myogenic tone was found to be sensitive to blockers of connexinbased gap junctions in resistance arteries [98-100]. In small mesenteric resistance arteries, the myogenic response was blocked by $18 \alpha$-glycyrrhetinic acid $(18 \alpha-\mathrm{GA})$ and the connexin mimetic peptide ${ }^{37,43} \mathrm{Gap} 27$, which blocks channels formed by Cx37 or Cx43 [98]. Interestingly, the inhibition of the myogenic vasoconstriction was associated with a reduction in the pressureinduced SMC depolarization and the subsequent $\mathrm{Ca}^{2+}$ influx, which suggested that the inhibition was not related to synchronization of $\mathrm{Ca}^{2+}$ signaling, but rather to earlier signaling events such as the initiation of SMCdepolarization [98]. It is important to note that the effect of connexin mimetic peptides such as ${ }^{37,}{ }^{43} \mathrm{Gap} 27$ on connexin channels is time dependent. It has been suggested that application of these peptides for short periods of time (from 10 to $45 \mathrm{~min}$ ) only inhibits hemichannel activity, without affecting gap junction communication, which are blocked only by much longer $(>1 \mathrm{hr}$ ) periods of treatment $[34,101-103]$. The myogenic response was evaluated only after $1 \mathrm{hr}$ of treatment with ${ }^{37},{ }^{43}$ Gap27, thus the contribution of gap junction channels and hemichannels must be further 
explored. Connexin hemichannels are mechanosensitive and, therefore, may directly form part of the vascular smooth muscle pressure-sensitive mechanism involved in the development of myogenic vasoconstriction [104]. As Cx37, but not 43, was detected by immunofluorescence in SMCs of these mesenteric arteries, the activation of Cx37 channels was proposed to be involved in the pressureinduced smooth muscle cell depolarization that triggers the initiation of the myogenic response [98]. However, the resting basal vasomotor tone of cremaster muscle arterioles of Cx37 knockout (KO) mice was not different to that observed in wild type animals, thus the participation of other Cxs, like Cx43 and/or pannexins cannot be definitively ruled out [15].

In addition to the myogenic tone, connexin hemichannels may also involved in the sympathetic nerve-triggered vasoconstriction. The sympathetic vasomotor tone is primarily mediated by norepinephrine-evoked activation of $\alpha 1$-adrenoceptors in SMCs [95]. It was recently reported that blockade of connexin-based channels with $18 \beta$-glycyrrhetinic acid (18 $\beta$-GA) or the Cx40 blocking peptide ${ }^{40} \mathrm{Gap} 27$ attenuates the increase in perfusion pressure induced by $\mathrm{PE}$ in isolated, perfused rat kidney, an effect observed within a few minutes of peptide application [105]. Furthermore, the vasoconstrictor response was not altered by the connexin-blocking peptides ${ }^{37,}{ }^{43} \mathrm{Gap} 27$ or ${ }^{43}$ Gap26, a Cx43-specific channel blocker, suggesting participation of $\mathrm{Cx} 40$ hemichannels in the response [105]. The inhibition of the vasoconstriction observed in the presence of ${ }^{40} \mathrm{Gap} 27$ suggests the participation of $\mathrm{Cx} 40$ hemichannels in the $\alpha 1$-adrenoceptor-mediated control of vasomotor tone; however, the mechanism involved has not been elucidated. This also highlights the serious problem of pharmacological reliance for determination of connexin hemichannel function. This therefor requires active investigation and the impetus is certainly on the connexin hemichannel field to definitely prove these exist in vivo and without the need to use vague inhibitors (e.g., as discussed by [106]).

The vasoconstrictor response initiated by $\alpha 1$-adrenoceptor activation in arterioles appears to be very complex and also involves autocrine signaling mediated by ATP release through pannexin channels. Recently Billaud et al. showed that stimulation of $\alpha 1$-adrenoceptors leads to Panx 1 channel opening, which provides the pathway for ATP release [63]. The ATP released via Panx 1 channels contributes, in great part, to the $\alpha 1$-adrenoceptor-mediated vasoconstriction through the activation of P2Y receptors $[62,63,107]$. Interestingly, this complementary vasoconstrictor mechanism is only coupled to $\alpha 1$-adrenoceptor activation while the response to serotonin or endothelin-1 is not affected by typical Panx1 channel blockers such as the Panx1 mimetic peptide ${ }^{10}$ Panx and probenecid, which was confirmed in the SMC Panx1-deficient mice [62]. This observation has now been confirmed independently pharmacologically [108] and genetically [109] in mouse mesenteric arterioles (as well as humans [data not shown]) highlighting the importance of the Panx1- $\alpha 1$-adrenerigc interaction, especially for translational outcomes.. The activation of Panx1 channels was found to rely on the specific amino acid sequence YLK, corresponding to residues 198 to 200 of the intracellular loop of Panx1 $[45,62,63]$. This suggests that phosphorylation at $\mathrm{Tyr}^{198}$ may mediate the $\alpha 1$-adrenoceptorinduced Panx1 channel opening, as recently reported by Lohman et al. to occur in the activation of Panx1 channels in venous ECs in response to TNF $\alpha[45,62,63]$.

\section{Connexins and pannexins in endothelial cell function}

ECs play a central role in the regulation of vasomotor tone primarily by the production of $\mathrm{Ca}^{2+}$-dependent vasodilator signals such as $\mathrm{NO}$, prostaglandins and $\mathrm{EDH}$ $[4,11,12,110]$. Interestingly, $\mathrm{NO}$ and prostaglandins have been shown to be released through connexin hemichannels $[78,111]$. It is important to note that NO may also induce the opening of hemichannels formed by the vascular connexins Cx37, Cx40 and Cx43, probably through $\mathrm{S}$-nitrosylation, as demonstrated in the case of $\mathrm{Cx} 43$ hemichannels [78, 84]. In addition, several reports show that ECs may release ATP, a potent endothelium-dependent vasodilator, through $\mathrm{Cx} 43$ hemichannels and Panx1 channels [45, 54, 90, 112-117]. Therefore, endothelial ATP release may be involved in the control of vasomotor tone. Consistent with this hypothesis, endothelial Panx1dependent ATP release was recently proposed to facilitate or enhance the EDH signal activated by ACh in ECs from mouse saphenous artery through a mechanism similar to that described for the response to PE in SMCs [118]. In this case; however, the increase of extracellular ATP concentration not only triggered the activation of P2 receptors directly by ATP, but also P1 receptors indirectly by the hydrolysis of ATP to adenosine, which was proposed to contribute to the ACh-induced increase in $\mathrm{EC}\left[\mathrm{Ca}^{2+}\right]_{\mathrm{i}}[118]$. Paradoxically, global deletion of Panx1 resulted in a selective reduction of the $\mathrm{SK}_{\mathrm{Ca}}$ and $\mathrm{IK}_{\mathrm{Ca}}$-initiated $\mathrm{EDH}$ mediated vasodilation, without affecting the NO-dependent vasodilator component of the response to $\mathrm{ACh}$, although both signals (EDH and $\mathrm{NO}$ ) are $\mathrm{Ca}^{2+}$-dependent [118]. Ablation of Panx1 in these animals did not evoke a compensatory change in the expression of Panx 2 or Panx 3 in the saphenous artery; thus, the mechanism by which Panx1driven ATP release activates selectively $\mathrm{SK}_{\mathrm{Ca}}$ and $\mathrm{IK}_{\mathrm{Ca}}$ in ECs will have to be addressed in further investigations [118].

\section{Connexins and pannexins in the vessel wall inflammatory response}

The role of connexin-based intercellular gap junction channels in inflammation has been investigated for decades. 
Multiple research groups have shown that connexin-based gap junctions play an important role regulating cell-to-cell communication during inflammation-related diseases such as atherosclerosis, hypertension or diabetes (for reviews see $[4,119,120])$. However, longstanding evidence also indicates that functional connexin hemichannels are involved in inflammation. While most research of connexin hemichannels in inflammation has been focused on the brain, by investigating astrocytes, neurons, and microglia (for reviews see $[121,122])$, there is in vitro evidence for both pro- and anti-inflammatory roles for connexin hemichannels in the vasculature (Table 2). Pannexin channels that are highly expressed throughout the immune and cardiovascular system $[45,123,124]$ are known to be key players during inflammation, but less is known about the mechanism by which pannexins participate in the cellular inflammatory response [125]. A role has been shown for pannexins in ischaemic conditions, pro-inflammatory neurotransmitter signaling, and surgically induced injuries on ECs that are presented below (Table 2).

\section{Role of connexin hemichannels and pannexin channels under inflammatory conditions}

To date, there are only few studies carving out the distinct regulation between the activation of connexin hemichannel and/or pannexin channels. Kaneko et al. for example showed a role for both connexin hemichannels and pannexin channels in a blood-brain barrier (BBB) model system [35]. Using the human cerebral microvascular endothelial cell line hCMEC/D3, conditions mimicking acute ischemic stroke led to the opening of both Cx43 hemichannels and Panx1 channels, as observed by increased dye uptake and calcein efflux, respectively. Pharmacological inhibition with CBX or $18 \alpha-\mathrm{GA}$ and knockdown with either Cx43 siRNA or Panx1 siRNA prevented the dye uptake and calcein efflux [35]. In another study, regulation of BBB ECs under inflammatory conditions was linked to connexin hemichannel opening; specifically bradykinin, a pro-inflammatory agent, evoked an increase in $\mathrm{BBB}$ permeability in rats through the activation of intracellular $\mathrm{Ca}^{2+}$ oscillations in ECs by a pathway sensitive to the $\mathrm{Cx} 43$ inhibitor Gap27, indicating the involvement of hemichannel opening and purinergic signaling in response to bradykinin [34].

Ischemic injuries resulting in inflammation also induce the opening of connexin hemichannels. In retinal ischemiareperfusion (I/R) injury in rat, the opening of $\mathrm{Cx} 43$ hemichannels and gap junctional communication was shown to play a role in inflammation, vascular permeability and neuronal death [126]. In a similar study, I/R led to

Table 2 Pathophysiological conditions linked to connexin hemichannel or pannexin channel regulation. EC: endothelial cells; MS: mesangial cells; n.d.: not determined

\begin{tabular}{|c|c|c|c|c|c|c|}
\hline Protein & Condition & Regulation & Cell type & Tissue origin & Species & Reference \\
\hline \multicolumn{7}{|c|}{ Connexin hemichannels $^{a}$} \\
\hline Cx43 & $\begin{array}{l}\text { Gram-positive bacterial cell wall component peptidoglycan-induced } \\
\text { immune response }\end{array}$ & Opening & EC & Brain & Mouse & [128] \\
\hline Cx43 & Hypoxia & Opening & EC & Brain & Rat & [124] \\
\hline Cx43 & Hypoxia & Closure & EC & Skin & Human & [54] \\
\hline Cx43 & Acute ischemic stroke mimicking (absence of extracellular $\mathrm{Ca}^{2+}$ ) & Opening & EC & Brain & Human & [35] \\
\hline Cx43 & Retinal ischemia-reperfusion injury & Opening & EC & Retina & Rat & [123] \\
\hline Cx43 & Retinal ischemia-reperfusion injury & Opening & EC & Retina & Rat & [124] \\
\hline Cx43 & Bradykinin-induced inflammation & Opening & EC & Brain & Rat/bovine & [34] \\
\hline Cx43 & Thrombin-induced inflammatory response & Closure & EC & Cornea & Bovine & [129] \\
\hline Cx43 & Diabetes (high glucose/cytokines treatment)-mimicking conditions & Opening & MS & Kidney & Mouse & [132] \\
\hline Cx43 & Surgical implantation of medical devices & Opening & EC & n.d. & Human/rat & [130] \\
\hline \multicolumn{7}{|c|}{ Pannexin channels ${ }^{\mathrm{a}}$} \\
\hline Panx1 & Acute ischemic stroke mimicking (absence of extracellular $\mathrm{Ca}^{2+}$ ) & Opening & EC & Brain & Human & [35] \\
\hline Panx1 & Cerebral ischemia-reperfusion injury & Opening & n.d. & Brain & Rat & [125] \\
\hline Panx1 & Pro-inflammatory neurotransmitter CGRP release & Opening & EC & Mesentery & Rat & [37] \\
\hline Panx1 & M-CSF-induced HSP-70 release immune response & Opening & EC & n.d. & Human & [126] \\
\hline Panx1 & TNFa-induced acute inflammation & Opening & EC & Diverse & Mouse/human & [45] \\
\hline Panx1 & Thrombin-induced inflammation & Opening & EC & Umbilical vein & Human & [112] \\
\hline Panx1 & Surgical harvesting of vessel & Opening & EC & Saphenous Vein & Human & [131] \\
\hline
\end{tabular}

${ }^{a}$ Note that the connexin hemichannel work has been proposed almost exclusively through pharmacological extrapolation, whereas the pannexin work combines genetic and pharmacological confirmation 
fragmented vessels, increased Evans Blue leakage into the retina, increased $\mathrm{Cx} 43$ expression, co-localization of activated astrocytes with ECs, and glial fibrillary acidic protein (GFAP) de-organization close to blood vessels resulting in retinal ganglion cell death [127]. These effects were prevented by treatment with $\mathrm{Cx} 43$ mimetic peptide during reperfusion, which strongly supports a Cx43 hemichannel-dependent mechanism during I/R injury [127]. Cerebral $I / R$ injury in rats induced activation of astrocytes, microglia and further subsequent inflammatory responses. Treatment of the animals before or even after the induced ischemia with different doses of probenecid, a pannexin inhibitor, prevented $I / R$ injury-induced inflammation and cell death by preventing increased expression of cathepsin $\mathrm{B}$ and calpain-1 and by increasing heat shock protein 70 (HSP70) release [128, 129]. Although these studies were done in different organs, namely retina and brain, they suggest a role of connexin hemichannels and pannexin channels in the $I / R$ injury.

Hypoxia alone also appears to independently regulate connexin-based hemichannel opening in vitro. In rat brain microvascular endothelial R840K-05a cells, hypoxiainduced cell death could be rescued by the application of hemichannel inhibitors carbenoxolone (CBX), $\mathrm{La}^{3+}$ or Cx43 mimetic peptide [127]. Interestingly, astrocytes at penetrating vessels in the medulla oblongata release ATP via Cx26 hemichannel under hypercapnia (elevated arterial $P_{\mathrm{CO} 2}$ ) to signal for breathing regulation [130]. Both conditions, low $\mathrm{O}_{2}$ levels and increased $\mathrm{CO}_{2}$ levels, signal via connexin hemichannel-mediated ATP release. However, studies also showed that in human microvascular ECs of dermal origin, induction of hypoxia for $48 \mathrm{~h}$ attenuated Cx43 hemichannel-mediated ATP release. In this study, Cx43 transcript, total, and surface protein levels were all reduced, and Cx43 showed higher phosphorylation at S368 (which leads to a closed state of this hemichannel) [54]. The regulation of $\mathrm{Cx} 43$ hemichannel activity as well as a potential role of pannexin channels in hypoxic conditions, remains to be investigated.

Exposure to pathogen-associated molecular patterns (PAMPs) causes the opening of $\mathrm{Cx} 43$ hemichannels in $\mathrm{ECs}$ of the BBB, which induces an early inflammatory process. Incubation of b.End5 cells, a murine brain endothelial cell line, with the gram-positive cell wall component peptidoglycan for $24 \mathrm{~h}$ induces an ATP release via PKC-dependent $\mathrm{Cx} 43$ hemichannel opening, resulting in increases in mRNA expression levels of Cx43, Interleukin-6 (IL-6) and Toll-like receptor 2 (TLR2). These results demonstrate the role of $\mathrm{Cx} 43$ hemichannels in early inflammatory response, which occurs before changing the inflammatory related gene expression [131]. Another proinflammatory TNFa-induced ATP release was shown to be Panx1-dependent. Lohman et al. recently identified an important mechanism of regulation of endothelial Panx1 channels in TNFo-induced inflammation ex vivo, using dissected mesenteric veins, and in vitro, using isolated human primary venous ECs [45]. Application of TNF $\alpha$ induced, within minutes, ATP release into the lumen of cannulated veins or into the media of cultured cells. Importantly, this effect was only seen in veins or venous ECs, but not in arteries or arterial ECs. This ATP release was Panx1 channel-mediated as shown by prevention of ATP release with pharmacological inhibitors, such as CBX or ${ }^{10} \mathrm{Panx}$, and with siRNA-mediated knockdown of Panx1. siRNA knockdown of Cx43, conversely, had no effect. Furthermore, cannulated veins from EC-specific Panx1deficient mice failed to release ATP following TNF $\alpha$ stimulation. TNFo induced SFK-dependent phosphorylation at tyrosine Y198 in the intracellular loop of Panx1, leading to the opening of the channel. Intravital microscopy demonstrated that TNF $\alpha$ induced leukocyte adhesion and emigration was blunted in EC-specific Panx1-deficient mice [45]. In a similar study, thrombin induced a robust, $\mathrm{Ca}^{2+}$-dependent ATP release via Panx1 channels in HUVECs [115]. Pro-inflammatory mediators like thrombin or histamine were also reported to induce the inhibition of Cx43 hemichannel-mediated ATP release by either a rapid and transient RhoA activation or the activation of phospholipase C (PLC), depending on which G protein was expressed in the cell [132]. These results highlight Panx1 as well as Cx hemichannels as a key protein for the crosstalk between cytokine and purinergic signaling in early inflammation.

In addition to known vascular diseases, surgical implantation of medical devices can also trigger inflammatory responses that involve connexin hemichannel activity. This inflammatory response leads to thickening of the implant/muscle interface and increased numbers of infiltrating neutrophils [133]. Application of a Cx43 mimetic peptide (JM2), which binds to the microtubule binding domain of $\mathrm{Cx} 43$, resulted in the inhibition of Cx43 hemichannel-mediated ATP release in cultured HMVEC [133]. When applied to rats with a silicone implant, the JM2 peptide restored the matrix formation and cellularity surrounding the implants and reduced the number of infiltrated neutrophils, suggesting that blockade of Cx43 hemichannel opening and subsequent ATP release into the vasculature could reduce inflammation and improve tissue healing after implant surgery [133]. Similar to $\mathrm{Cx} 43$ hemichannel regulation during surgical intervention, surgical harvesting of human saphenous veins induced endothelial and/or smooth muscle injuries resulting in cellular dysfunction and intimal thickening, possibly due to ischemia in the vein following extraction. Intimal injuries during surgery led to ATP release, which evoked $\mathrm{P} 2 \mathrm{X}_{7}$ receptor and/or Panx1 channel activation with subsequent $\mathrm{P}_{2} \mathrm{X}_{7}$ receptor downstream signaling. 
Pharmacological inhibition of Panx 1 and $\mathrm{P}_{2} \mathrm{X}_{7} \mathrm{R}$ with probenecid and oxidized ATP, respectively, prevented inflammatory intimal hyperplasia and, therefore, could be a possible therapeutic target for improving successful grafting of vessels [134].

A functional role of Panx1 was also suggested in the signaling between the nervous and vascular system under pro-inflammatory conditions. Stimulation of primary arterial endothelial mesenteric cells and intact mesenteric arteries with the neurotransmitter calcitonin gene-related peptide (CGRP) leads to Panx1 channel opening as shown by ethidium uptake, which was prevented by the specific inhibition of CGRP receptors with the peptide CGRP $_{8-37}$ or the blockade of Panx1 channels with probenecid. Furthermore, stimulation of perivascular sensory nerves with capsaicin led to CGRP release and downregulation of endothelial NOS (eNOS) expression, linking pro-inflammatory induced neurotransmitter release to the development of endothelial dysfunction during inflammation via decreased eNOS protein levels [37]. A possible role for connexin hemichannels was not investigated.

The development of renal and cellular alterations during diabetes in rats has been linked to increased Cx43 hemichannel opening in mesangial cells, specialized cells surrounding blood vessels in the kidney. Mouse MES-13 mesangial cells treated with high glucose and cytokines (tumor necrosis factor $\alpha$ (TNF $\alpha$ ), IL-1 $\beta$ ) for $48 \mathrm{~h}$ displayed an increase in cellular permeability that correlated with an enhanced uptake of ethidium bromide, suggesting an increase in connexin hemichannel opening [135]. However, pannexin channels cannot be ruled out and necessitate further pharmacological or genetic experiments. Taken together the data predominately suggest that preventing/reducing connexin hemichannel or pannexin channel opening may reduce inflammation in response to various stimuli.

Connexins and pannexins in anuclear circulating blood cells Pannexins in RBCs Long viewed simply as carriers of oxygen, in the past two decades red blood cells (RBCs) have received renewed attention for their potential 'erythrocrine' function; i.e., the ability to influence their own distribution across the vasculature by participating in signaling pathways that result in the modulation of vascular tone, thus controlling blood flow to tissues with relatively greater or lesser need of oxygenation [7, 136, 137]. Ellsworth et al. proposed in 1995 a pathway involving RBC release of ATP into the vessel lumen based on the knowledge that RBCs release ATP in response to hypoxic conditions and that ATP application results in significant increases in RBC supply rate to both arterioles and venules at the end of a capillary network $[136,138]$. ATP released by RBCs is thought to bind to G protein-coupled P2Y receptors on the endothelium, initiating a signaling cascade to produce and release peripheral vasodilatory signaling molecules such as $\mathrm{NO}$ and prostacyclin [136]. Upstream transmission of this vasodilator response allows blood flow to be modulated to match local oxygen demand [139]. ATP is released when human RBCs are exposed to $\mathrm{O}_{2}$ tensions equivalent to $50 \%$ hemoglobin oxygen saturation [140]. Further supporting the central role of RBCs in this process, perfusion of blood vessels with RBCs was shown to be necessary to elicit vessel dilation in response to hypoxia [141]. This phenomenon is also supported by exercise data showing that changes in the levels of circulating ATP in blood plasma are proportional to changes in the oxygenation state of hemoglobin in RBCs [137].

A mechanism for ATP release was provided by the detection of functional Panx1 channels in RBCs, and by the lack of $\mathrm{Cx} 43$ and vesicular release of ATP in RBCs under physiological conditions (Table 3) [142, 143]. Inhibition of RBC ATP release with the pannexin inhibitors $\mathrm{CBX}$, probenecid, and ${ }^{10}$ Panx later clarified that Panx 1 is responsible for ATP release from human RBCs in response to hypoxia, though not for a separate mechanism of ATP release in response to activation of the prostacyclin receptor [144]. Additionally, mechanical deformation of RBCs has been found to induce ATP release via a pathway similar to that of hypoxia-induced ATP release, with impairment of RBC deformability also impairing hypoxic ATP release $[140,145]$. The exact mechanism of Panx1 opening in response to hypoxia or RBC deformation remains unsolved, but a variety of data suggests that Panx1 lies downstream of the mechanosensitive $G$ protein-coupled receptor $G_{i}$, (e.g. P2Y receptors), adenylyl cyclase, and cAMP synthesis $[140,144,146]$. However, RBCs are still able to release ATP in response to direct $G_{i}$ stimulation when RBC deformation is prevented. These observations suggest that hypoxia and deformation of RBCs is linked, possibly by $G_{i}$ to initiate the signaling cascade culminating in Panx1-dependent release of ATP into the vessel lumen [145]. The resulting NO that serves as a vasodilator may,

Table 3 Expression pattern of connexin and pannexin isoforms in red blood cells (RBCs) and platelets. 'no' indicates that a protein has yet to be identified in those cells

\begin{tabular}{llll}
\hline Protein & RBCs & Platelets & References \\
\hline Cx32 & no & low levels & {$[147]$} \\
Cx37 & no & yes & {$[146,147]$} \\
Cx40 & no & yes & {$[147]$} \\
Cx43 & no & low levels & {$[147]$} \\
Panx1 & yes & yes & {$[139,140] /[149,150]$} \\
Panx2 & no & no & \\
Panx3 & no & no & \\
\hline
\end{tabular}


in turn, inhibit ATP release in a negative feedback loop [140]. While the mechanism has not been fully explained, this negative feedback is thought to occur via NO-derived inactivation of $G_{i}[146]$. However, the recent discovery that Panx1 can be inhibited directly by NO via S-nitrosylation on amino acid residues C40 and C346 offers an alternative explanation that must be investigated [90].

Connexins and Pannexins in Platelets Platelets are anuclear cells found in blood that, in the presence of endothelial damage, bind exposed collagen on the basement membrane of the vessel wall. Further, they are activated to release $\alpha$-granules that contain a variety of growth and clotting factors and dense granules that contain ADP, ATP, $\mathrm{Ca}^{2+}$, serotonin, and histamine; signals that promote further platelet aggregation [147]. Certain pathologic conditions result in elevated platelet activity outside of normal hemostasis, including chronic infectious or inflammatory conditions such as atherosclerosis [147]. When an atherosclerotic plaque ruptures, platelets erroneously become activated, often leading to thrombosis and possible vessel occlusion [148]. Interrupting pathogenic platelet activation and aggregation is therefore an important strategy to prevent and combat thrombosis.

The most common connexin found on the surface of human platelets by immunohistochemistry is Cx37, with lower amounts of $\mathrm{Cx} 32, \mathrm{Cx} 40$, and $\mathrm{Cx} 43$ also reported (Table 3) $[149,150]$. Platelet $\alpha$-granule and dense granule secretion was significantly reduced after platelets were stimulated with collagen-related peptide (CRP-XL) in the presence of connexin inhibitors, ${ }^{37,43} \mathrm{Gap} 27, \mathrm{CBX}$ or $18 \beta-G A$, suggesting a role for connexin hemichannels during platelet activation [150]. In addition, connexin inhibitors decreased binding of individual platelets to fibrinogen and inhibited platelet aggregation [150]. However, Cx37-deficient mouse platelets did not reveal a significant difference in $\alpha$-granule and dense granule secretion compared to WT platelets when stimulated with CRP-XL, implicating a connexin other than Cx37 mediates platelet granule secretion [150]. Overall, the findings of Vaiyapuri et al. suggest that connexin hemichannel activity plays an important role in platelet activation and initiation of aggregation via fibrinogen binding.

Interestingly, ${ }^{40} \mathrm{Gap} 27$-treated human platelets and Cx40-deficient mouse platelets both showed decreased fibrinogen binding compared to WT when platelets were stimulated with CRP-XL [151]. Inhibition or deletion of Cx40 in platelets also showed significantly decreased expression of P-selectin, a marker of $\alpha$-granule secretion [151]. These studies may support a role for Cx40 hemichannels, in promoting platelet activation and aggregation. Further investigation of how $\mathrm{Cx} 40$ hemichannels may be activated is required.
Panx1 has also been identified on the surface of human platelets, but not Panx2 or Panx3 [152, 153]. Panx1 inhibition or deletion in platelets resulted in impaired collagen-induced aggregation, ATP release, and $\mathrm{Ca}^{2+}$ influx [152, 153]. Molica et al. reported that, in platelets, Panx1 co-immunoprecipitates with $\mathrm{P}_{2} \mathrm{X}_{1}$, an ATP-gated channel involved in thrombosis [152]. Inhibition of $\mathrm{P}_{2} \mathrm{X}_{1}$ with NF449 decreased collagen-induced platelet aggregation, which was not restored by potassium-stimulated opening of Panx1 channels [152]. Taylor et al. found that the Panx1 inhibitors probenecid and CBX, impaired collagen, thrombin, and $\mathrm{TXA}_{2}$ analogue-induced $\mathrm{Ca}^{2+}$ influx, possibly through $\mathrm{P}_{2} \mathrm{X}_{1}$ signaling $[153,154]$. Together, these data suggest that $\mathrm{P} 2 \mathrm{X}_{1}$ signaling occurs downstream of Panx1 [152-154]. Platelets from patients homozygous for the Panx1-400C polymorphism, which results in a change from glutamine to histamine at residue 5 in the Panx1 amino-terminus, release elevated amounts of ATP at rest when stimulated with $\mathrm{K}^{+}$and demonstrate increased collagen-induced platelet reactivity compared to platelets with the Panx1-400A allele coding for glutamine [152]. In addition, a higher frequency of the Panx1-400C allele was found in cardiovascular patients with hyperreactive platelets compared to those with hypo-reactive platelets [152]. Further evaluation of connexin- and pannexin-dependent signaling in platelets may provide a new therapeutic target for cardiovascular patients.

\section{Conclusions}

Connexin hemichannels and Panx channels may play an important role in the vascular system, not only in the coordination of endothelial and smooth muscle cell signaling, but also in the control of blood cell function in normal conditions as well as during inflammation. Although several connexin and Panx isoforms are expressed in the vessel wall and blood cells, the signaling mediated by connexin hemichannels and Panx channels in the vascular system seems to rely mainly on channels formed by Cx43 and Panx1, respectively. Both Cx43 and Panx1 have several sites that can be modulated by phosphorylation and S-nitrosylation, which provides mechanisms for rapid and fine regulation of the activity of these channels and for cross talk between the interactions of different signaling pathways.

The most relevant signaling mechanism mediated by connexin hemichannels and Panx channels between the cells of the vascular system is the release of ATP. However, connexin hemichannels and Panx channels are also permeable to $\mathrm{Ca}^{2+}$, which is a key second messenger in the control of vasomotor tone by both endothelial cells and smooth muscle cells. In any case, the possible direct contribution of these channels to the regulation of intracellular $\mathrm{Ca}^{2+}$ dynamics in the cells of the vessel wall remains to be determined. In addition, although most cells 
of the vascular system express connexins and Panx channels, it should be noted that the function of these channels is not redundant, as can be observed, for instance, in the vasoconstriction of smooth muscle cells initiated by intravascular blood pressure (i.e. myogenic response) or $\alpha 1$-adrenoceptor activation. The functional specificity of these channels suggests that the manipulation of their activity may provide the opportunity to design novel pharmacological strategies for the treatment of diseases associated with the development of vascular dysfunction or inflammation.

In summary, although multiple connexin and pannexin isoforms have been found in the vasculature as well as the anuclear circulating cells, their channel regulations and functions remain a topic of intense investigation. The separation between connexin hemichannel and pannexin channel function is difficult to ascertain, however it remains vital to explore these mechanisms as there are both convergent and divergent functions throughout the vasculature to maintain homeostasis.

\section{Declarations}

This article has been published as part of BMC Cell Biology Volume 18 Supplement 1, 2017: Proceedings of the International Gap Junction Conference 2015: second issue. The full contents of the supplement are available online at http://bmccellbiol.biomedcentral.com/articles/ supplements/volume-18-supplement-1.

\section{Funding}

This work was supported by National Institutes of Health grants HL088554 (B.E.I.), HL120840 (B.E.I.), HL131399 (M.E.G), and CV Training Grant HL007284 (M.E.G.) and Grant \#1150530 from Fondo Nacional de Desarrollo Científico y Tecnológico - FONDECYT (X.F.F.).

\section{Availability of data and material}

Not applicable.

\section{Authors' contributions}

$D B, M E G, A S K, L J D, C R$, BEl and XFF wrote and revised the manuscript. All authors read and approved the final manuscript.

\section{Consent for publication}

Not applicable.

\section{Ethics and approval and consent to participate}

Not applicable.

\section{Author details \\ ${ }^{1}$ Robert M Berne Cardiovascular Research Center, University of Virginia School of Medicine, Charlottesville, VA 22908, USA. ${ }^{2}$ Department of Molecular Physiology and Biophysics, University of Virginia School of Medicine, Charlottesville, VA, USA. ${ }^{3}$ Departamento de Fisiología, Facultad de Ciencias Biológicas, Pontificia Universidad Católica de Chile, Santiago, Chile.}

Published: 17 January 2017

\section{References}

1. Davis MJ, Ferrer PN, Gore RW. Vascular anatomy and hydrostatic pressure profile in the hamster cheek pouch. Am J Phys. 1986;250(2 Pt 2):H291-303.

2. Lockhart CJ, Hamilton PK, Quinn CE, McVeigh GE. End-organ dysfunction and cardiovascular outcomes: the role of the microcirculation. Clin Sci (Lond). 2009;116(3):175-90.

3. Mulvany MJ, Aalkjaer C. Structure and function of small arteries. Physiol Rev. 1990;70(4):921-61
4. Figueroa XF, Duling BR. Gap junctions in the control of vascular function. Antioxid Redox Signal. 2009;11(2):251-66.

5. Segal SS. Integration of blood flow control to skeletal muscle: key role of feed arteries. Acta Physiol Scand. 2000;168(4):511-8.

6. Segal SS. Regulation of blood flow in the microcirculation. Microcirculation. 2005:12(1):33-45.

7. Cortese-Krott MM, Kelm M. Endothelial nitric oxide synthase in red blood cells: key to a new erythrocrine function? Redox Biol. 2014;2:251-8.

8. Rossaint J, Zarbock A. Platelets in leucocyte recruitment and function. Cardiovasc Res. 2015;107(3):386-95.

9. Lohman AW, Billaud M, Isakson BE. Mechanisms of ATP release and signalling in the blood vessel wall. Cardiovasc Res. 2012;95(3):269-80.

10. Moncada S. Adventures in vascular biology: a tale of two mediators. Philos Trans R Soc Lond Ser B Biol Sci. 2006;361(1469):735-59.

11. Moncada S, Palmer RM, Higgs EA. Nitric oxide: physiology, pathophysiology, and pharmacology. Pharmacol Rev. 1991;43(2):109-42.

12. Vanhoutte PM. COX-1 and vascular disease. Clin Pharmacol Ther. 2009:86(2):212-5.

13. Busse R, Edwards G, Feletou M, Fleming I, Vanhoutte PM, Weston AH. EDHF: bringing the concepts together. Trends Pharmacol Sci. 2002;23(8):374-80.

14. Feletou M, Vanhoutte PM. EDHF: an update. Clin Sci (Lond). 2009;117(4):139-55.

15. Figueroa XF, Duling BR. Dissection of two Cx37-independent conducted vasodilator mechanisms by deletion of $\mathrm{C} \times 40$ : electrotonic versus regenerative conduction. Am J Physiol Heart Circ Physiol. 2008:295(5):H2001-7.

16. Figueroa XF, Isakson BE, Duling BR. Connexins: gaps in our knowledge of vascular function. Physiology (Bethesda). 2004;19:277-84.

17. Jobs A, Schmidt K, Schmidt VJ, Lubkemeier I, van Veen TA, Kurtz A, Willecke K, de Wit C. Defective Cx40 maintains Cx37 expression but intact Cx40 is crucial for conducted dilations irrespective of hypertension. Hypertension. 2012;60(6):1422-9.

18. Bruzzone R, Hormuzdi SG, Barbe MT, Herb A, Monyer H. Pannexins, a family of gap junction proteins expressed in brain. Proc Natl Acad Sci U S A. 2003; 100(23):13644-9.

19. Lohman AW, Isakson BE. Differentiating connexin hemichannels and pannexin channels in cellular ATP release. FEBS Lett. 2014;588(8):1379-88.

20. Panchin YV. Evolution of gap junction proteins-the pannexin alternative. J Exp Biol. 2005;208(Pt 8):1415-9.

21. Saez JC, Berthoud VM, Branes MC, Martinez AD, Beyer EC. Plasma membrane channels formed by connexins: their regulation and functions. Physiol Rev. 2003;83(4):1359-400

22. Abascal F, Zardoya R. Evolutionary analyses of gap junction protein families. Biochim Biophys Acta. 2013;1828(1):4-14.

23. Sohl G, Willecke K. Gap junctions and the connexin protein family. Cardiovasc Res. 2004;62(2):228-32.

24. Ambrosi C, Gassmann O, Pranskevich JN, Boassa D, Smock A, Wang J, Dahl G, Steinem C, Sosinsky GE. Pannexin1 and Pannexin2 channels show quaternary similarities to connexons and different oligomerization numbers from each other. J Biol Chem. 2010;285(32):24420-31.

25. Goodenough DA, Paul DL. Beyond the gap: functions of unpaired connexon channels. Nat Rev Mol Cell Biol. 2003;4(4):285-94.

26. Shestopalov VI, Panchin Y. Pannexins and gap junction protein diversity. Cell Mol Life Sci. 2008;65(3):376-94.

27. Salameh A. Life cycle of connexins: regulation of connexin synthesis and degradation. Adv Cardiol. 2006;42:57-70.

28. Brisset AC, Isakson BE, Kwak BR. Connexins in vascular physiology and pathology. Antioxid Redox Signal. 2009;1 1(2):267-82.

29. Gabriels JE, Paul DL. Connexin43 is highly localized to sites of disturbed flow in rat aortic endothelium but connexin37 and connexin40 are more uniformly distributed. Circ Res. 1998;83(6):636-43.

30. Matchkov W, Rahman A, Bakker LM, Griffith TM, Nilsson H, Aalkjaer C. Analysis of effects of connexin-mimetic peptides in rat mesenteric small arteries. Am J Physiol Heart Circ Physiol. 2006;291(1):H357-67.

31. Wagner C. Function of connexins in the renal circulation. Kidney Int. 2008;73(5):547-55.

32. Little TL, Beyer EC, Duling BR. Connexin 43 and connexin 40 gap junctional proteins are present in arteriolar smooth muscle and endothelium in vivo. Am J Phys. 1995;268(2 Pt 2):H729-39.

33. Pogoda K, Fuller M, Pohl U, Kameritsch P. NO, via its target $\mathrm{C} \times 37$, modulates calcium signal propagation selectively at myoendothelial gap junctions. Cell Commun Signal. 2014;12:33.

34. De Bock M, Culot M, Wang N, Bol M, Decrock E, De Vuyst E, da Costa A, Dauwe I, Vinken M, Simon AM, et al. Connexin channels provide a target to manipulate brain endothelial calcium dynamics and blood-brain barrier permeability. J Cereb Blood Flow Metab. 2011;31(9):1942-57. 
35. Kaneko Y, Tachikawa M, Akaogi R, Fujimoto K, Ishibashi M, Uchida Y, Couraud PO, Ohtsuki S, Hosoya K, Terasaki T. Contribution of pannexin 1 and connexin 43 hemichannels to extracellular calcium-dependent transport dynamics in human blood-brain barrier endothelial cells. J Pharmacol Exp Ther. 2015;353(1):192-200.

36. Traub O, Hertlein B, Kasper M, Eckert R, Krisciukaitis A, Hulser D, Willecke K Characterization of the gap junction protein connexin37 in murine endothelium, respiratory epithelium, and after transfection in human HeLa cells. Eur J Cell Biol. 1998;77(4):313-22.

37. Gaete PS, Lillo MA, Figueroa XF. Functional role of connexins and pannexins in the interaction between vascular and nervous system. J Cell Physiol. 2014; 229(10):1336-45

38. Munger SJ, Kanady JD, Simon AM. Absence of venous valves in mice lacking Connexin37. Dev Biol. 2013;373(2):338-48.

39. Chang CJ, Wu LS, Hsu LA, Chang GJ, Chen CF, Yeh HI, Ko YS. Differential endothelial gap junction expression in venous vessels exposed to different hemodynamics. J Histochem Cytochem. 2010;58(12):1083-92.

40. Miquerol L, Thireau J, Bideaux P, Sturny R, Richard S, Kelly RG. Endothelial plasticity drives arterial remodeling within the endocardium after myocardial infarction. Circ Res. 2015;116(11):1765-71.

41. Begandt D, Bader A, Gerhard L, Lindner J, Dreyer L, Schlingmann B, Ngezahayo A. Dipyridamole-related enhancement of gap junction coupling in the GM-7373 aortic endothelial cells correlates with an increase in the amount of connexin 43 mRNA and protein as well as gap junction plaques. J Bioenerg Biomembr. 2013;45(4):409-19.

42. Kruger O, Plum A, Kim JS, Winterhager E, Maxeiner S, Hallas G, Kirchhoff S, Traub O, Lamers WH, Willecke K. Defective vascular development in connexin 45-deficient mice. Development. 2000;127(19):4179-93.

43. Okamoto T, Akiyama M, Takeda M, Gabazza EC, Hayashi T, Suzuki K. Connexin32 is expressed in vascular endothelial cells and participates in gap-junction intercellular communication. Biochem Biophys Res Commun. 2009;382(2):264-8.

44. Lohman AW, Billaud M, Straub AC, Johnstone SR, Best AK, Lee M, Barr K, Penuela S, Laird DW, Isakson BE. Expression of pannexin isoforms in the systemic murine arterial network. J Vasc Res. 2012;49(5):405-16.

45. Lohman AW, Leskov IL, Butcher JT, Johnstone SR, Stokes TA, Begandt D, DeLalio LJ, Best AK, Penuela S, Leitinger N, et al. Pannexin 1 channels regulate leukocyte emigration through the venous endothelium during acute inflammation. Nat Commun. 2015;6:7965.

46. Burns AR, Phillips SC, Sokoya EM. Pannexin protein expression in the rat middle cerebral artery. J Vasc Res. 2012;49(2):101-10.

47. Somlyo AP, Somlyo AV. Signal transduction by G-proteins, rho-kinase and protein phosphatase to smooth muscle and non-muscle myosin II. J Physiol. 2000:522(Pt 2):177-85

48. Cooke JP, Dzau VJ. Nitric oxide synthase: role in the genesis of vascular disease. Annu Rev Med. 1997:48:489-509.

49. Johnstone SR. Going against the flow: the connexin connection in hypertension. Hypertension. 2015;65(3):502-4.

50. Penuela S, Harland L, Simek J, Laird DW. Pannexin channels and their links to human disease. Biochem J. 2014:461(3):371-81.

51. Johnstone S, Isakson B, Locke D. Biological and biophysical properties of vascular connexin channels. Int Rev Cell Mol Biol. 2009;278:69-118.

52. Solan JL, Lampe PD. Connexin43 phosphorylation: structural changes and biological effects. Biochem J. 2009;419(2):261-72.

53. Saez JC, Retamal MA, Basilio D, Bukauskas FF, Bennett MV. Connexin-based gap junction hemichannels: gating mechanisms. Biochim Biophys Acta. 2005;1711(2):215-24

54. Faigle M, Seessle J, Zug S, El Kasmi KC, Eltzschig HK. ATP release from vascular endothelia occurs across Cx43 hemichannels and is attenuated during hypoxia. PLoS One. 2008;3(7):e2801.

55. Song M, Yu X, Cui X, Zhu G, Zhao G, Chen J, Huang L. Blockade of connexin 43 hemichannels reduces neointima formation after vascular injury by inhibiting proliferation and phenotypic modulation of smooth muscle cells. Exp Biol Med (Maywood). 2009;234(10):1192-200

56. Toma I, Bansal E, Meer EJ, Kang JJ, Vargas SL, Peti-Peterdi J. Connexin 40 and ATP-dependent intercellular calcium wave in renal glomerular endothelial cells. Am J Physiol Regul Integr Comp Physiol. 2008;294(6):R1769-76.

57. D'Hondt C, lyyathurai J, Vinken M, Rogiers V, Leybaert L, Himpens B, Bultynck $\mathrm{G}$. Regulation of connexin- and pannexin-based channels by post-translational modifications. Biol Cell. 2013;105(9):373-98.

58. Lampe PD, Lau AF. Regulation of gap junctions by phosphorylation of connexins. Arch Biochem Biophys. 2000;384(2):205-15.
59. Lampe PD, TenBroek EM, Burt JM, Kurata WE, Johnson RG, Lau AF. Phosphorylation of connexin43 on serine 368 by protein kinase $C$ regulates gap junctional communication. J Cell Biol. 2000;149(7):1503-12.

60. Bao X, Lee SC, Reuss L, Altenberg GA. Change in permeant size selectivity by phosphorylation of connexin 43 gap-junctional hemichannels by PKC. Proc Natl Acad Sci U S A. 2007:104(12):4919-24.

61. Bao X, Reuss L, Altenberg GA. Regulation of purified and reconstituted connexin 43 hemichannels by protein kinase C-mediated phosphorylation of Serine 368. J Biol Chem. 2004;279(19):20058-66.

62. Billaud M, Chiu YH, Lohman AW, Parpaite T, Butcher JT, Mutchler SM, DeLalio LJ, Artamonov MV, Sandilos JK, Best AK, et al. A molecular signature in the pannexin 1 intracellular loop confers channel activation by the alpha1 adrenoreceptor in smooth muscle cells. Sci Signal. 2015:8(364):ra17.

63. Billaud M, Lohman AW, Straub AC, Looft-Wilson R, Johnstone SR, Araj CA, Best AK, Chekeni FB, Ravichandran KS, Penuela S, et al. Pannexin1 regulates alpha1adrenergic receptor- mediated vasoconstriction. Circ Res. 2011;109(1):80-5.

64. Good ME, Begandt D, DeLalio LJ, Keller AS, Billaud M, Isakson BE. Emerging concepts regarding pannexin 1 in the vasculature. Biochem Soc Trans. 2015:43(3):495-501.

65. Penuela S, Bhalla R, Gong XQ, Cowan KN, Celetti SJ, Cowan BJ, Bai D, Shao Q, Laird DW. Pannexin 1 and pannexin 3 are glycoproteins that exhibit many distinct characteristics from the connexin family of gap junction proteins. J Cell Sci. 2007;120(Pt 21):3772-83.

66. Omasits $\mathrm{U}$, Ahrens $\mathrm{CH}$, Muller S, Wollscheid B. Protter: interactive protein feature visualization and integration with experimental proteomic data. Bioinformatics. 2014:30(6):884-6.

67. Hornbeck PV, Zhang B, Murray B, Kornhauser JM, Latham V, Skrzypek E. PhosphoSitePlus, 2014: mutations, PTMs and recalibrations. Nucleic Acids Res. 2015:43(Database issue):D512-20.

68. Pullamsetti SS, Berghausen EM, Dabral S, Tretyn A, Butrous E, Savai R, Butrous G, Dahal BK, Brandes RP, Ghofrani HA, et al. Role of Src tyrosine kinases in experimental pulmonary hypertension. Arterioscler Thromb Vasc Biol. 2012;32(6):1354-65

69. Abebe W, Agrawal DK. Role of tyrosine kinases in norepinephrine-induced contraction of vascular smooth muscle. J Cardiovasc Pharmacol. 1995;26(1):153-9.

70. Hughes AD, Wijetunge $\mathrm{S}$. Role of tyrosine phosphorylation in excitationcontraction coupling in vascular smooth muscle. Acta Physiol Scand. 1998;164(4):457-69.

71. Weilinger NL, Tang PL, Thompson RJ. Anoxia-induced NMDA receptor activation opens pannexin channels via Src family kinases. J Neurosci. 2012;32(36):12579-88

72. Iglesias R, Locovei S, Roque A, Alberto AP, Dahl G, Spray DC, Scemes E. P2X7 receptor-Pannexin1 complex: pharmacology and signaling. Am J Physiol Cell Physiol. 2008;295(3):C752-60.

73. Riquelme MA, Cea LA, Vega JL, Boric MP, Monyer H, Bennett MV, Frank M, Willecke K, Saez JC. The ATP required for potentiation of skeletal muscle contraction is released via pannexin hemichannels. Neuropharmacology. 2013;75:594-603.

74. Poornima V, Vallabhaneni S, Mukhopadhyay M, Bera AK. Nitric oxide inhibits the pannexin 1 channel through a cGMP-PKG dependent pathway. Nitric Oxide. 2015:47:77-84.

75. Lee MR, Li L, Kitazawa T. Cyclic GMP causes Ca2+ desensitization in vascular smooth muscle by activating the myosin light chain phosphatase. J Biol Chem. 1997;272(8):5063-8.

76. Hess DT, Stamler JS. Regulation by S-nitrosylation of protein posttranslational modification. J Biol Chem. 2012;287(7):4411-8.

77. Hess DT, Matsumoto A, Kim SO, Marshall HE, Stamler JS. Protein S-nitrosylation: purview and parameters. Nat Rev Mol Cell Biol. 2005;6(2):150-66.

78. Figueroa XF, Lillo MA, Gaete PS, Riquelme MA, Saez JC. Diffusion of nitric oxide across cell membranes of the vascular wall requires specific connexin-based channels. Neuropharmacology. 2013;75:471-8.

79. McKinnon RL, Lidington D, Bolon M, Ouellette $Y$, Kidder GM, Tyml K. Reduced arteriolar conducted vasoconstriction in septic mouse cremaster muscle is mediated by nNOS-derived NO. Cardiovasc Res. 2006;69(1):236-44.

80. McKinnon RL, Bolon ML, Wang HX, Swarbreck S, Kidder GM, Simon AM, Tyml K. Reduction of electrical coupling between microvascular endothelial cells by NO depends on connexin37. Am J Physiol Heart Circ Physiol. 2009;297(1):H93-101.

81. Straub AC, Billaud M, Johnstone SR, Best AK, Yemen S, Dwyer ST, Looft-Wilson R, Lysiak JJ, Gaston B, Palmer L, et al. Compartmentalized connexin 43 s-nitrosylation/denitrosylation regulates heterocellular communication in the vessel wall. Arterioscler Thromb Vasc Biol. 2011;31(2):399-407. 
82. Munoz MF, Puebla M, Figueroa XF. Control of the neurovascular coupling by nitric oxide-dependent regulation of astrocytic $\mathrm{Ca}(2+)$ signaling. Front Cell Neurosci. 2015;9:59.

83. Kondo RP, Wang SY, John SA, Weiss JN, Goldhaber Jl. Metabolic inhibition activates a non-selective current through connexin hemichannels in isolated ventricular myocytes. J Mol Cell Cardiol. 2000;32(10):1859-72.

84. Retamal MA, Cortes CJ, Reuss L, Bennett MV, Saez JC. S-nitrosylation and permeation through connexin 43 hemichannels in astrocytes: induction by oxidant stress and reversal by reducing agents. Proc Natl Acad Sci U S A. 2006;103(12):4475-80.

85. Zhang L, Deng T, Sun Y, Liu K, Yang Y, Zheng X. Role for nitric oxide in permeability of hippocampal neuronal hemichannels during oxygen glucose deprivation. J Neurosci Res. 2008;86(10):2281-91.

86. Thompson RJ, Zhou N, MacVicar BA. Ischemia opens neuronal gap junction hemichannels. Science. 2006;312(5775):924-7.

87. Prochnow N, Hoffmann S, Dermietzel R, Zoidl G. Replacement of a single cysteine in the fourth transmembrane region of zebrafish pannexin 1 alters hemichannel gating behavior. Exp Brain Res. 2009;199(3-4):255-64.

88. Bunse S, Schmidt M, Prochnow N, Zoidl G, Dermietzel R. Intracellular cysteine 346 is essentially involved in regulating Panx1 channel activity. J Biol Chem. 2010;285(49):38444-52.

89. Bunse S, Schmidt M, Hoffmann S, Engelhardt K, Zoidl G, Dermietzel R. Single cysteines in the extracellular and transmembrane regions modulate pannexin 1 channel function. J Membr Biol. 2011;244(1):21-33.

90. Lohman AW, Weaver JL, Billaud M, Sandilos JK, Griffiths R, Straub AC, Penuela S, Leitinger N, Laird DW, Bayliss DA, et al. S-nitrosylation inhibits pannexin 1 channel function. J Biol Chem. 2012;287(47):39602-12.

91. Harnett KM, Biancani P. Calcium-dependent and calcium-independent contractions in smooth muscles. Am J Med. 2003;115(Suppl 3A):24S-30.

92. Moosmang S, Lenhardt P, Haider N, Hofmann F, Wegener JW. Mouse models to study L-type calcium channel function. Pharmacol Ther. 2005;106(3):347-55.

93. Jackson WF. lon channels and vascular tone. Hypertension. 2000;35(1 Pt 2):173-8.

94. Kuo L, Chilian WM, Davis MJ. Interaction of pressure- and flow-induced responses in porcine coronary resistance vessels. Am J Phys. 1991;261(6 Pt 2):H1706-15.

95. Guimaraes S, Moura D. Vascular adrenoceptors: an update. Pharmacol Rev. 2001;53(2):319-56.

96. Hill MA, Davis MJ, Meininger GA, Potocnik SJ, Murphy TV. Arteriolar myogenic signalling mechanisms: Implications for local vascular function. Clin Hemorheol Microcirc. 2006;34(1-2):67-79.

97. Murphy TV, Spurrell BE, Hill MA. Cellular signalling in arteriolar myogenic constriction: involvement of tyrosine phosphorylation pathways. Clin Exp Pharmacol Physiol. 2002;29(7):612-9.

98. Earley S, Resta TC, Walker BR. Disruption of smooth muscle gap junctions attenuates myogenic vasoconstriction of mesenteric resistance arteries. Am J Physiol Heart Circ Physiol. 2004;287(6):H2677-86.

99. Lagaud G, Karicheti V, Knot HJ, Christ GJ, Laher I. Inhibitors of gap junctions attenuate myogenic tone in cerebral arteries. Am J Physiol Heart Circ Physiol. 2002;283(6):H2177-86.

100. Young EJ, Hill MA, Wiehler WB, Triggle CR, Reid JJ. Reduced EDHF responses and connexin activity in mesenteric arteries from the insulin-resistant obese Zucker rat. Diabetologia. 2008;51(5):872-81.

101. Braet K, Aspeslagh S, Vandamme W, Willecke K, Martin PE, Evans WH, Leybaert L. Pharmacological sensitivity of ATP release triggered by photoliberation of inositol-1,4,5-trisphosphate and zero extracellular calcium in brain endothelial cells. J Cell Physiol. 2003;197(2):205-13.

102. Eltzschig HK, Eckle T, Mager A, Kuper N, Karcher C, Weissmuller T, Boengle K, Schulz R, Robson SC, Colgan SP. ATP release from activated neutrophils occurs via connexin 43 and modulates adenosine-dependent endothelial cell function. Circ Res. 2006;99(10):1100-8.

103. Evans $W H$, De Vuyst $E$, Leybaert $L$. The gap junction cellular internet: connexin hemichannels enter the signalling limelight. Biochem J. 2006:397(1):1-14.

104. Bao L, Sachs F, Dahl G. Connexins are mechanosensitive. Am J Physiol Cell Physiol. 2004;287(5):C1389-95.

105. Piao H, Sato A, Nozawa Y, Sun W, Morioka T, Oite T. Effects of connexin-mimetic peptides on perfusion pressure in response to phenylephrine in isolated, perfused rat kidneys. Clin Exp Nephrol. 2011;15(2):203-11.

106. Esseltine JL, Laird DW. Next-Generation Connexin and Pannexin Cell Biology. Trends Cell Biol. 2016.

107. Billaud M, Sandilos JK, Isakson BE. Pannexin 1 in the regulation of vascular tone. Trends Cardiovasc Med. 2012;22(3):68-72.
108. Angus JA, Wright CE. Novel alpha1-adrenoceptor antagonism by the fluroquinolone antibiotic trovafloxacin. Eur J Pharmacol. 2016;791:179-84.

109. Kauffenstein G, Tamareille S, Prunier F, Roy C, Ayer A, Toutain B, Billaud M, Isakson BE, Grimaud L, Loufrani L, et al. Central Role of P2Y6 UDP Receptor in Arteriolar Myogenic Tone. Arterioscler Thromb Vasc Biol. 2016:36(8):1598-606.

110. Moncada S, Higgs EA. Nitric oxide and the vascular endothelium. Handb Exp Pharmacol. 2006(176 Pt 1):213-254.

111. Cherian PP, Siller-Jackson AJ, Gu S, Wang X, Bonewald LF, Sprague E, Jiang JX. Mechanical strain opens connexin 43 hemichannels in osteocytes: a novel mechanism for the release of prostaglandin. Mol Biol Cell. 2005;16(7):3100-6.

112. Buvinic S, Poblete MI, Donoso MV, Delpiano AM, Briones R, Miranda R, Huidobro-Toro JP. P2Y1 and P2Y2 receptor distribution varies along the human placental vascular tree: role of nucleotides in vascular tone regulation. J Physiol. 2006:573(Pt 2):427-43.

113. Duza T, Sarelius $\Vdash H$. Conducted dilations initiated by purines in arterioles are endothelium dependent and require endothelial Ca2+. Am J Physiol Heart Circ Physiol. 2003;285(1):H26-37.

114. Winter P, Dora KA. Spreading dilatation to luminal perfusion of ATP and UTP in rat isolated small mesenteric arteries. J Physiol. 2007;582(Pt 1):335-47.

115. Godecke S, Roderigo C, Rose CR, Rauch BH, Godecke A, Schrader J. Thrombin-induced ATP release from human umbilical vein endothelial cells. Am J Physiol Cell Physiol. 2012;302(6):C915-23.

116. Gomes P, Srinivas SP, Van Driessche W, Vereecke J, Himpens B. ATP release through connexin hemichannels in corneal endothelial cells. Invest Ophthalmol Vis Sci. 2005;46(4):1208-18.

117. Gomes P, Srinivas SP, Vereecke J, Himpens B. ATP-dependent paracrine intercellular communication in cultured bovine corneal endothelial cells. Invest Ophthalmol Vis Sci. 2005;46(1):104-13.

118. Gaynullina D, Shestopalov VI, Panchin Y, Tarasova OS. Pannexin 1 facilitates arterial relaxation via an endothelium-derived hyperpolarization mechanism. FEBS Lett. 2015;589(10):1164-70.

119. Chadjichristos CE, Derouette JP, Kwak BR. Connexins in atherosclerosis. Adv Cardiol. 2006:42:255-67.

120. Looft-Wilson RC, Billaud M, Johnstone SR, Straub AC, Isakson BE. Interaction between nitric oxide signaling and gap junctions: effects on vascular function. Biochim Biophys Acta. 2012;1818(8):1895-902.

121. Takeuchi $H$, Suzumura A. Gap junctions and hemichannels composed of connexins: potential therapeutic targets for neurodegenerative diseases. Front Cell Neurosci. 2014:8:189.

122. Bennett MV, Garre JM, Orellana JA, Bukauskas FF, Nedergaard M, Saez JC. Connexin and pannexin hemichannels in inflammatory responses of glia and neurons. Brain Res. 2012;1487:3-15.

123. Chekeni FB, Elliott MR, Sandilos JK, Walk SF, Kinchen JM, Lazarowski ER, Armstrong AJ, Penuela S, Laird DW, Salvesen GS, et al. Pannexin 1 channels mediate 'find-me' signal release and membrane permeability during apoptosis. Nature. 2010:467(7317):863-7.

124. Kanneganti TD, Lamkanfi M, Kim YG, Chen G, Park JH, Franchi L, Vandenabeele P, Nunez G. Pannexin-1-mediated recognition of bacterial molecules activates the cryopyrin inflammasome independent of Toll-like receptor signaling. Immunity. 2007;26(4):433-43.

125. Adamson SE, Leitinger N. The role of pannexin1 in the induction and resolution of inflammation. FEBS Lett. 2014;588(8):1416-22.

126. Kerr NM, Johnson CS, Zhang J, Eady EK, Green CR, Danesh-Meyer HV. High pressure-induced retinal ischaemia reperfusion causes upregulation of gap junction protein connexin43 prior to retinal ganglion cell loss. Exp Neurol. 2012:234(1):144-52.

127. Danesh-Meyer HV, Kerr NM, Zhang J, Eady EK, O'Carroll SJ, Nicholson LF, Johnson CS, Green CR. Connexin43 mimetic peptide reduces vascular leak and retinal ganglion cell death following retinal ischaemia. Brain. 2012; 135(Pt 2):506-20.

128. Wei R, Wang J, Xu Y, Yin B, He F, Du Y, Peng G, Luo B. Probenecid protects against cerebral ischemia/reperfusion injury by inhibiting lysosomal and inflammatory damage in rats. Neuroscience. 2015;301:168-77.

129. Thuringer D, Berthenet K, Cronier L, Jego G, Solary E, Garrido C. Oncogenic extracellular HSP70 disrupts the gap-junctional coupling between capillary cells. Oncotarget. 2015;6(12):10267-83.

130. Huckstepp RT, id Bihi R, Eason R, Spyer KM, Dicke N, Willecke K, Marina N, Gourine AV, Dale N. Connexin hemichannel-mediated CO2-dependent release of ATP in the medulla oblongata contributes to central respiratory chemosensitivity. J Physiol. 2010;588(Pt 20):3901-20. 
131. Robertson J, Lang S, Lambert PA, Martin PE. Peptidoglycan derived from Staphylococcus epidermidis induces Connexin43 hemichannel activity with consequences on the innate immune response in endothelial cells. Biochem J. 2010:432(1):133-43.

132. Ponsaerts R, D'Hondt C, Hertens F, Parys JB, Leybaert L, Vereecke J, Himpens B, Bultynck G. RhoA GTPase switch controls Cx43-hemichannel activity through the contractile system. PLoS One. 2012;7(7):e42074.

133. Calder BW, Matthew Rhett J, Bainbridge H, Fann SA, Gourdie RG, Yost MJ. Inhibition of connexin 43 hemichannel-mediated ATP release attenuates early inflammation during the foreign body response. Tissue Eng Part A. 2015;21(11-12):1752-62.

134. Voskresensky IV, Wise ES, Hocking KM, Li FD, Osgood MJ, Komalavilas P, Brophy C, Cheung-Flynn J. Brilliant blue FCF as an alternative dye for saphenous vein graft marking: effect on conduit function. JAMA Surg. 2014;149(11):1176-81.

135. Hernandez-Salinas R, Vielma AZ, Arismendi MN, Boric MP, Saez JC, Velarde V. Boldine prevents renal alterations in diabetic rats. J Diabetes Res. 2013;2013:593672.

136. Ellsworth $\mathrm{ML}$, Forrester $\mathrm{T}$, Ellis $\mathrm{CG}$, Dietrich $\mathrm{HH}$. The erythrocyte as a regulator of vascular tone. Am J Physiol Heart Circ Physiol. 1995;269(6): H2155-61.

137. Gonzalez-Alonso J, Olsen DB, Saltin B. Erythrocyte and the regulation of human skeletal muscle blood flow and oxygen delivery: role of circulating ATP. Circ Res. 2002;91(11):1046-55.

138. Bergfeld GR, Forrester T. Release of ATP from human erythrocytes in response to a brief period of hypoxia and hypercapnia. Cardiovasc Res. 1992;26(1):40-7.

139. Ellsworth ML. Red blood cell-derived ATP as a regulator of skeletal muscle perfusion. In: Med Sci Sports Exerc. vol. 36. United States; 2004: 35-41.

140. Sprague RS, Ellsworth ML. Erythrocyte-derived ATP and perfusion distribution: role of intracellular and intercellular communication. Microcirculation. 2012:19(5):430-9.

141. Dietrich HH, Ellsworth ML, Sprague RS, Dacey Jr RG. Red blood cell regulation of microvascular tone through adenosine triphosphate. Am J Physiol Heart Circ Physiol. 2000;278(4):H1294-8.

142. Qiu F, Wang J, Spray DC, Scemes E, Dahl G. Two non-vesicular ATP release pathways in the mouse erythrocyte membrane. FEBS Lett. 2011;585(21):3430-5.

143. Locovei S, Bao L, Dahl G. Pannexin 1 in erythrocytes: function without a gap. Proc Natl Acad Sci U S A. 2006;103(20):7655-9.

144. Sridharan M, Adderley SP, Bowles EA, Egan TM, Stephenson AH, Ellsworth ML, Sprague RS. Pannexin 1 is the conduit for low oxygen tension-induced ATP release from human erythrocytes. Am J Physiol Heart Circ Physiol. 2010; 299(4):H1146-52.

145. Sridharan M, Spraque RS, Adderley SP, Bowles EA, Ellsworth ML, Stephenson AH. Diamide decreases deformability of rabbit erythrocytes and attenuates low oxygen tension-induced ATP release. Exp Biol Med (Maywood). 2010;235(9):1142-8.

146. Olearczyk JJ, Stephenson AH, Lonigro AJ, Sprague RS. NO inhibits signal transduction pathway for ATP release from erythrocytes via its action on heterotrimeric G protein Gi. Am J Physiol Heart Circ Physiol. 2004;287(2): H748-54.

147. Gibbins JM. Platelet adhesion signalling and the regulation of thrombus formation. J Cell Sci. 2004;117(Pt 16):3415-25.

148. Hansson GK. Inflammation, atherosclerosis, and coronary artery disease. N Engl J Med. 2005;352(16):1685-95.

149. Angelillo-Scherrer A, Fontana P, Burnier L, Roth I, Sugamele R, Brisset A, Morel S, Nolli S, Sutter E, Chassot A, et al. Connexin 37 limits thrombus propensity by downregulating platelet reactivity. Circulation. 2011;124(8):930-9.

150. Vaiyapuri S, Jones Cl, Sasikumar P, Moraes LA, Munger SJ, Wright JR, Ali MS, Sage T, Kaiser WJ, Tucker KL, et al. Gap junctions and connexin hemichannels underpin hemostasis and thrombosis. Circulation. 2012;125(20):2479-91.

151. Vaiyapuri S, Moraes LA, Sage T, Ali MS, Lewis KR, Mahaut-Smith MP, Oviedo-Orta E, Simon AM, Gibbins JM. Connexin40 regulates platelet function. Nat Commun. 2013;4:2564

152. Molica F, Morel S, Meens MJ, Denis JF, Bradfield PF, Penuela S, Zufferey A, Monyer $\mathrm{H}$, Imhof BA, Chanson $\mathrm{M}$, et al. Functional role of a polymorphism in the Pannexin 1 gene in collagen-induced platelet aggregation. In: Thromb Haemost, vol. 114. 2015.
153. Taylor KA, Wright JR, Vial C, Evans RJ, Mahaut-Smith MP. Amplification of human platelet activation by surface pannexin-1 channels. J Thromb Haemost. 2014;12(6):987-98.

154. Fung C, Cendana C, Farndale R, Mahaut-Smith M. Primary and secondary agonists can use $\mathrm{P} 2 \mathrm{X} 1$ receptors as a major pathway to increase intracellular Ca2+ in the human platelet. J Thromb Haemost. 2007;5:910-7.

\section{Submit your next manuscript to BioMed Central and we will help you at every step:}

- We accept pre-submission inquiries

- Our selector tool helps you to find the most relevant journal

- We provide round the clock customer support

- Convenient online submission

- Thorough peer review

- Inclusion in PubMed and all major indexing services

- Maximum visibility for your research

Submit your manuscript at www.biomedcentral.com/submit 